\title{
Paulina Pieńkowska
}

\section{Rola Jane Wilhelminy Stirling w życiu Fryderyka Chopina oraz w kultywowaniu dziedzictwa i pamięci o kompozytorze}

Postać Jane Wilhelminy Stirling jest dziś niemal zapomniana. W powszechnej świadomości, kiedy myśli się o kobietach, które wywarły wpływ na życie i twórczość Fryderyka Chopina, przywołuje się nazwiska Konstancji Gładkowskiej, Marii Wodzińskiej, George Sand, jej córki Solange Clésinger, Delfiny Potockiej czy Marceliny Czartoryskiej. Tymczasem o Jane Stirling nie wspomina się szerzej nawet w biografiach uznawanych w chopinologii za podstawowe ${ }^{1}$. Zwykle opisuje się ją jako osobę, która przyczyniła się do przedwczesnej śmierci kompozytora organizując jego wyczerpującą podróż do Anglii i Szkocji bądź jako uczennicę bez wzajemności zakochaną w Chopinie. Niewielu więc ma świadomość, jak ważną rolę Jane Stirling odegrała w życiu kompozytora i w zachowaniu pamięci o nim po jego śmierci. Jak pisze Bożena Weber: „nie jesteśmy w stanie ciągle jeszcze w pełni rozeznać, ile należy zabiegom i jej przezorności zawdzięczać” ${ }^{2}$. W swoim artykule chciałabym wyjść naprzeciw tym brakom, w sposób systematyczny próbując przedstawić w jednym miejscu wszystkie informacje na temat Stirling, jej związku z Fryderykiem Chopinem oraz roli w kultywowaniu dziedzictwa i pamięci o kompozytorze.

1 M.in. pozycje Mieczysława Tomaszewskiego, Zofii Jeżewskiej i Adama Czartkowskiego.

2 B. Weber, Chopin, Wrocław 200o, s. 192. 


\section{Jane Wilhelmina Stirling i jej relacja z Chopinem - kontekst biograficzny}

Jane Wilhelmina Stirling urodziła się 15 lipca 1804 roku$^{3}$ w Kippenross House w Dunblane, ale Szkocka Encyklopedia Kobiet podaje, że ochrzczono ją już 8 kwietnia 1804 roku$^{4}$. Pochodziła z arystokratycznej rodziny, była trzynastym, najmłodszym dzieckiem Johna Stirlinga i Mary Stirling, drugiej córki Williama Grahama z Airth ${ }^{5}$. Nie dysponujemy prawie żadnymi informacjami na temat jej życia. Pewne jest to, że ze względu na wczesną śmierć rodziców Stirling spędziła dzieciństwo w Szkocji pod opieką swojej starszej siostry Katherine Erskine. W drugiej połowie 1826 roku Jane wraz z siostrą udała się do Paryża i od tego czasu nieustannie podróżowała między Szkocją a stolicą Francji.

Niestety, jak dotąd nie udało się precyzyjnie ustalić, kiedy Jane poznała Fryderyka Chopina. Według niektórych źródeł została jego uczennicą w roku $1842^{6}$, według innych w $1843^{7}$. Audrey Evelyn Bone doszukuje się początku ich kontaktów już w roku $1832^{8}$, nie potwierdza tego jednak żaden dokument. Jean-Jacques Eigeldinger wspomina natomiast, że Jane pobierała lekcje u Lindaya Slopera ${ }^{9}$ zanim została przez niego przedstawiona Chopinowi. Sloper z kolei przebywał w Paryżu w latach $1841-1846^{10}$, zatem rzekome kontakty Stirling i Chopina w latach trzydziestych, jakie sugeruje Bone, są raczej wątpliwe. Sam Sloper w rozmowie z Frederickiem Niecksem przyznał, że Jane bardzo chciała

3 Tę datę wskazuje m.in. David Wright oraz potomkowie Jane Stirling. Por. D.C.F. Wright, Frederick Chopin, [online] http://www.wrightmusic.net/pdfs /frederick-chopin.pdf [dostęp: 29.08.2016], s. 11; [online] http://janestirling.com /Obchody-urodzin-Jane-12.html [dostęp: 18.02.2017].

4 The Biographical Dictionary of Scottish Women. From the Earliest Times to 2004, red. E. Ewan, S. Innes, S. Reynolds, Edinburgh 2006, s. 345.

5 [b.a.] Clan Stirling Online, [online] http://www.clanstirling.org/pdf /AirdofKippendavie.pdf [dostęp: 20.11.2016], s. 3.

6 P. Willis, Chopin in Britain. Chopin's Visits to England and Scotland in 1837 and 1848. People, Places and Activities, Durham 2009, s. 55.

7 [b.a.] Kalendarium życia Chopina. Rok 1843, [online] http://pl.chopin.nifc.pl/chopin /life/calendar/year/1843 [dostęp: 21.11.2016].

8 A.E. Bone, Jane Wilhelmina Stirling, 1804-1859. The First Study of the Life of Chopin's Pupil and Friend, Chipstead 1960, s. 39.

9 J.-J. Eigeldinger, Chopin w oczach swoich uczniów, tłum. Z. Skowron, Kraków 2010, s. 227.

10 F. Niecks, Fryderyk Chopin jako człowiek i muzyk, tłum. A. Buchner, Warszawa 2011, s. 486. 
zostać uczennicą Chopina, więc postanowił przedstawić ją polskiemu kompozytorowi. Podobno Chopinowi spodobała się gra Jane, ponadto bardzo ją polubił ${ }^{11}$. Miał nawet wówczas powiedzieć: „Kiedyś będzie pani grać bardzo, bardzo dobrze"12. Cenił ją wysoko jako uczennicę. Po śmierci Fryderyka Jane kształciła się także u Thomasa Tellefsena.

Wspomnienia i wzmianki osób, które ją znały, przybliżają nam nieco tę niezwykłą postać - we wszystkich przewija się pamięć o jej niezwykłej dobroci, oddaniu dla innych, mądrości i pobożności. Solange Clésinger tak pisała o niej i jej siostrze:

\section{W godzinach lekcji spotykało się u Mistrza dwie wysokie postacie, typowe rodowite Szkotki, chude, blade, w nieokreślonym wieku, poważne, czarno ubrane, nie uśmiechające się nigdy. Pod tą nieco ponurą powierzchownością kryły się dwa serca wzniosłe, szlachetne i oddane ${ }^{13}$.}

W życiu Jane Bóg pełnił bardzo ważną rolę. Wszystko robiła w zgodzie z religią, zawsze podkreślała jej wartość. Wielokrotnie napomykała o tym w listach do Ludwiki Jędrzejewicz, siostry Chopina: „Jeden dzień, jedna godzina może tyle zmienić w życiu! Nabierzmy odwagi i stańmy z czystym sercem przed Bogiem, aby przybyć do domu bratniego" ${ }^{14}$.

W tym miejscu należy też wspomnieć o wyjątkowej relacji łączącej Jane z Chopinem. Po dziś dzień nie jesteśmy w stanie ustalić, na czym więź ta polegała. Wielu badaczy sugeruje, że Stirling była zakochana w kompozytorze. W pewnym sensie przejęła rolę George Sand - jako opiekunki - w życiu Chopina, kiedy ten rozstał się z pisarką: dbała o niego, spędzała z nim wiele czasu. W związku z tym część kręgu znajomych Fryderyka Chopina zaczęła uważać, że kompozytor niedługo weźmie ślub ze Stirling. Jednak on sam nigdy nie miał planów małżeńskich w stosunku do Jane, co skwitował w liście do Wojciecha Grzymały, pisanym w Szkocji 30 października 1848 roku:

11 Tamże, s. 487.

12 Cyt. za: [b.a.], Osoby zwiazane z Chopinem. Jane Wilhelmina Stirling, [online] http://pl.chopin.nifc.pl/chopin/persons/detail/id/457 [dostęp: 21.11.2016].

13 Cyt. za: J.-J. Eigeldinger, Chopin w oczach..., dz. cyt., s. 228.

14 List Jane Stirling do Ludwiki Jędrzejewicz, Paryż, 3 stycznia 185o, cyt. za: H. Wróblewska-Straus, Listy Jane Wilhelminy Stirling do Ludwiki Jędrzejewiczowej, „Rocznik Chopinowski” 1980, nr 12, s. 76. 
Moje Szkotki poczciwe [...], ale takie nudne, że niech P. Bóg chowa!... Co dzień listy odbieram, na żaden nie odpisuję i jak tylko gdzie pojadę, tak za mną przyciągną, jeżeli mogą. To może myśl komu dało, że się żenię; ale jednakże trzeba fizycznego jakiego attrait, a za bardzo do mnie podobna ta, co nieżeniata. Jakże się z sobą samym całować... Przyjaźń przyjaźnią, wyraźnie powiedziałem, ale prawa do niczego innego nie daje ${ }^{15}$.

Dlaczego Chopin w tak kategorycznym tonie napisał do Grzymały? Zazwyczaj nie podejmował tematu uczuć, gdyż ta sfera życia stanowiła dla niego temat tabu. Prawdopodobnie był zdenerwowany plotkami o jego hipotetycznym małżeństwie. Także Adolf Gutmann, ulubiony uczeń Chopina, przekazał, że kompozytor w pewnym momencie powiedział mu: „Żenili mnie z Panną Stirling; równie dobrze mogłaby sobie wziąć śmierć za męża"16.

Współcześni Chopinowi, którzy znali kompozytora i Jane Stirling bezpośrednio, bardzo często pisali o niezwykłej relacji pomiędzy mistrzem a jego uczennicą. Na przykład niejaka pani Łyszczyńska, żona profesora Łyszczyńskiego, u którego Chopin spędził w Szkocji kilka dni, powiedziała Niecksowi: „Panna Stirling była mu niezwykle oddana [...]. Była znacznie starsza od Chopina, a jej miłość do niego, choć bardzo gorąca, była najzupełniej platoniczna"17.

To niecodzienne uczucie Jane do kompozytora trwało najwyraźniej i po jego śmierci. Do końca życia uważała ona Chopina za kogoś niezwykłego. Częstokroć w jej korespondencji spotykamy się z fragmentami, w których zastanawia się, co w danej sytuacji powiedziałby Chopin, jak zareagowałby, co uważałby za właściwe. Zwracała też uwagę na detale, przykładowo zostawiała kwiaty na grobie kompozytora od kwiaciarza, do którego ten chodził za życia ${ }^{18}$. Warto w tym miejscu przytoczyć fragmenty cytowanej już korespondencji pomiędzy Stirling a Ludwiką Jędrzejewicz. Jane pisze m.in.:

15 List Fryderyka Chopina do Wojciecha Grzymały, Edynburg, 30 października 1848, cyt. za: B.E. Sydow, Korespondencja Fryderyka Chopina, t. 2, Warszawa 1955, s. 285. Cyt. za: F. Niecks, dz. cyt., s. 486.

17 Cyt. za: tamże, s. 487.

18 M. Karłowicz, Niewydane dotąd pamiatki po Chopinie, Warszawa 1904, s. 336. 
Robiłam sobie wyrzuty za to, że pisałam o chorobie Pani Franchomme. Chopin nie uczyniłby tego. On zawsze myślał o tym, aby oszczędzić swym bliskim cierpienia ${ }^{19}$.

oraz:

Jeśli chodzi o sztukę, nie ma nikogo, kto by go mógł zastąpić, a wszyscy czujemy się tak, jakbyśmy potracili głowy. Nie wiem jak się wypowiedzieć, jego chciałabym zapytać, wszak rozumiał on tyle wyobrażeń, tyle swoistych uczuć, jakich inni nie pojmowali ${ }^{20}$.

Nie mamy zatem bezpośredniego źródła potwierdzającego teorię, że Jane Stirling żywiła do Chopina jakiekolwiek uczucia ponad przyjaźń, a jedyne wzmianki o jej miłości do polskiego kompozytora odnajdziemy w źródłach pośrednich. Korespondencja pomiędzy Stirling a Jędrzejewicz pokazuje jednak, jaką czcią i kultem Jane otaczała Chopina, co implicite wskazuje na uczucia, jakie do niego żywiła. Stirling nigdy nie wyszła za mąż i być może Chopin był pierwszym mężczyzną, którego obdarzyła uczuciem. Jednak prawdy na ten temat nie poznamy prawdopodobnie nigdy.

\section{Rola Jane Stirling w życiu Fryderyka Chopina}

Jane Wilhelmina Stirling nie tylko brała u Fryderyka Chopina lekcje gry na fortepianie, ale także $\mathrm{z}$ wielkim zaangażowaniem starała się na różne sposoby pomagać swemu mistrzowi. Jednym ze sposobów było zorganizowanie dla polskiego kompozytora tournée po Anglii i Szkocji (1848). Podróż ta została już kilkukrotnie opisana ${ }^{21}$, dlatego nie będę skupiać się na niej w niniejszej pracy. Warto jednak zaznaczyć, że bez pomocy uczennicy Chopin prawdopodobnie nie wyjechałby z Paryża w tak długą podróż, nie miałby szansy na zagranie tak dużej liczby koncertów oraz na tak wygodne i dostatnie warunki pobytu w Anglii i Szkocji. Jak pisał w liście do Wojciecha Grzymały: „Poczciwe Erskiny myślały

19 Cyt. za: H. Wróblewska-Straus, Listy..., dz. cyt., s. 84.

20 List Jane Stirling do Ludowki Jędrzejewicz, Paryż, 9-11 lutego 1850, cyt. za: tamże, s. 95.

21 Zob. np. P. Willis, dz. cyt.; F. Niecks, dz. cyt. 
o wszystkim, nawet o czekoladzie, nie tylko o mieszkaniu, które jednakże zmienię, bo od wczoraj jest na ich samej ulicy lepsze za 4 gw"22. Jane zatroszczyła się o wynajęcie mieszkania Chopinowi, uwzględniając każdy detal - począwszy od poszukiwań odpowiedniego lokum, aż do subtelnych udogodnień życia kompozytora, tak by czuł się w Anglii jak w domu. Sam Chopin niewątpliwie dostrzegał te starania: „Nie uwierzysz, jakie dobre; dopiero teraz widzę, że ten papier, na którym piszę, jest z moją cyfrą i mnóstwo takich małych delikatności zastałem"23.

Trudno jest dziś ocenić, czy Jane Stirling właściwie postąpiła, zabierając Chopina do Anglii. Wyjazd miał polepszyć sytuację materialną kompozytora - choć mogło to być tylko pretekstem, a Jane zabrała go w podróż z egoistycznych pobudek, chcąc jak najdłużej z nim przebywać, uzależnić od swojej pomocy, a może i przekonać do wspólnej przyszłości. Jak pisze Kazimierz Wierzyński:

Nieoględność panny Stirling, która chcąc pomóc ukochanemu człowiekowi, robiła wszystko, by przyspieszyć jego zgubę, wydaje się być niepojęta [...]. Wolno przypuszczać, że winna była temu nieporadna, nieszczęśliwa miłość. [...] Zachłanne jej uczucie uczepiło się myśli, że po wyjeździe z Francji Chopin należy do niej, że może pozostać w Anglii i potrzebować pomocy. Panna Stirling szukała zapewne potwierdzenia tych nadziei, a Chopin zapewne ich unikał ${ }^{24}$.

Tak czy inaczej, wkład Stirling w zorganizowanie całej podróży jest nieoceniony. Można spekulować, czy gdyby kompozytor został w Paryżu, żyłby dłużej. Zastanawia jednak, skąd czerpałby środki do życia.

Sytuacja materialna Fryderyka Chopina po jego powrocie z Londynu nie była najlepsza. $Z$ początkiem 1849 roku kompozytor ograniczył liczbę lekcji i nie przyjmował nowych uczniów. Dlatego Jane Stirling prawdopodobnie starała się wesprzeć Chopina materialnie - także poprzez anonimowe datki.

Z listów kompozytora dowiadujemy się, że otrzymał on darowiznę w wysokości 25000 franków przed 26 lipca 1849 roku. Pieniądze zostały przekazane przez anonimowego posłańca pani Étienne, która roznosiła

22 List Fryderyka Chopina do Wojciecha Grzymały, Londyn, 21 kwietnia 1848, cyt. za: B.E. Sydow, dz. cyt., s. 241.

23 Tamże, s. 241.

24 Kazimierz Wierzyński, Życie Chopina, Białystok 199o, s. 566. 
listy i zajmowała się mieszkaniem kompozytora od $1845 \mathrm{roku}^{25}$. Kobieta nie oddała jednak datku kompozytorowi, a schowała go w „mebliku koło łóżka" ${ }^{26}$. Chopin otrzymał przesyłkę dopiero po zamieszaniu związanym związanym z jej odzyskaniem, w które włączony był nawet tajemniczy Alexis Somnambul ${ }^{27}$. Reakcję kompozytora na zawartość przesyłki dobrze przedstawia cytat $\mathrm{z}$ listu do Grzymały z 28 lipca 1848 roku:

\footnotetext{
Nie był odpieczętowany i 25 tysięcy w nim nietknięte. U mnie pani Erskine go odpieczętowała, przy mnie i tym panu. Cóż Ty na to? Ten somnambul!!! Ten pakiet, tak dawno zarzucony, nietknięty!!! Głowa pęka na takie szczególne wypadki. - Można miarkować, żem donacji nie przyjął, i wiele by o tym pisać28.
}

Nie mamy bezpośredniego potwierdzenia, kto był nadawcą przesyłki. W liście do Wojciecha Grzymały z 28 lipca 1849 roku Chopin tak pisał o dalszych wydarzeniach:

Po Twej odpowiedzi i jej liście ręce mi opadły i nie wiedziałem, czy ją o halucynację, czy jej afidesa za złodzieja, czy panią Étienne posądzać, czy siebie za zapominalskiego mieć albo wariata, słowem - łeb mi pękał. Była u mnie z konfesjami i tak głupio mi odpowiadała, i siostra niby nic o tym nie wiedziała, że aż musiałem wiele prawd powiedzieć, jako to, że od nikogo, chyba od Królowej angielskiej albo miss Coutty rozumiałbym takie hojne podarunki itd. ${ }^{29}$.

List ten nie mówi zatem, kto był u Chopina $\mathrm{z}$ konfesjami, jednak wzmianka o siostrze od razu skierowała uwagę badaczy ku siostrom Jane i Katherine. W tym samym liście do Wojciecha Grzymały Chopin

25 O roli pani Étienne świadczą liczne wzmianki w listach Chopina. Na przykład w korespondencji do Marii de Roziéres z 21 lipca 1845 roku nadmieniał: „Piszę o tym wszystkim po to, żeby Pani zechciała postarać się o doręczenie tego drugiego listu, który przesyłam, niejakiemu p. Mikuliemu. Pani Étienne zna jego adres. Proszę ją poprosić, aby list zaniosła i kazała sobie dać pokwitowanie". Cyt. za: B.E. Sydow, dz. cyt., s. 143 .

26 Tamże, s. 310.

27 Kompozytor dowiedział się, że ktoś nadał mu list, którego nigdy nie otrzymał. Prawdopodobnie zapytał posłańca, dlaczego listu nie dostarczył. Posłaniec skierował się do Alexisa Somnambula i poprosił go o wyjaśnienie sprawy. Alexis wyjaśnił mu, że „on go nie ma, że go oddał w małym, ciemnym jakimciś pokoju, gdzie się po 2 schodach schodzi, jakiejś kobiecie”. Cyt. za: tamże.

28 Tamże, s. 311. Podkreślenia w tym i kolejnych cytatach pochodzą od Fryderyka Chopina.

29 Tamże, s. 310. 
wspomina: „Dziś rano przychodzi do mnie ten pan afides z Panią Erskine od Alexego" ${ }^{30}$, co świadczy o tym, że osobą, która wcześniej przyszła się tłumaczyć, była siostra Jane Stirling. Poza tym kompozytor w kolejnym liście do Grzymały pisze: „Co się mojego szczególnego wypadku tycze, wiele, wiele szczególnych rzeczy jest, które i z magnetyzmem, i ze łgarstwem albo halucynacją (P. St[irling - przyp. P.P.]) i z poczciwością pani Étienne zgodzić nie mogę" ${ }^{31}$.

Słuszność powyższych wniosków jako jedyni podali w wątpliwość Cecilia i Jens Jorgensenowie ${ }^{32}$. Przedstawili oni hipotezę, iż Chopin miał mieć plany matrymonialne związane $\mathrm{z}$ osobą Jenny Lind i że to właśnie szwedzka śpiewaczka, a nie Jane Stirling, była ową „nieżeniatą" z listu do Grzymały z 30 października 1848 roku. Jorgenstenowie uważają także, iż cytat ze wspomnianego listu kompozytora „poszedł do Alexego Somnambula" odnosi się do postaci Lind, która w roku 1848 śpiewała tytułową rolę w operze Lunatyczka (La Sonnambula) Belliniego. Zatem i kolejne wzmianki Chopina o Somnambulu w listach do Grzymały z 28 lipca i 3 sierpnia 1849 roku miałyby wskazywać na Lind. Szwedzcy badacze uważają także, że cytat: „ten Alexis mi we łbie" odnosi się do uczucia Chopina do $\operatorname{Lind}^{33}$. Alexis Somnambul wspomniany przez Chopina to jednak postać historyczna - człowiek zajmujący się magnetyzmem, lunatykowaniem, snem na jawie ${ }^{34}$, stąd prawdopodobnie przydomek Somnambul (lunatyk) odnosi się do jego profesji, a nie rzekomo ukrytej pod tym przezwiskiem osoby Jenny Lind.

Hipoteza ta opiera się jednak w dużej mierze na spekulacjach, a wnioski są bardzo często oparte tylko na wyrwanych z kontekstu fragmentach tłumaczeń (angielskich i francuskich) listów Chopina. Dlatego jest ona niespójna i pozostawia wiele do życzenia. Mimo to niektórzy chopinolodzy, m.in. Irena Poniatowska czy Hanna Wróblewska-Straus, nie mają jednoznacznego zdania $\mathrm{w}$ tej kwestii ${ }^{35}$ i wypowiadają się

30 Tamże.

31 Tamże, s. 312.

32 C. i J. Jorgensen, Chopin and the Swedish Nightingale, Brussels 2003.

33 Jednak myśli kompozytora nurtował prawdopodobnie po prostu Alexis, który odkrył na podstawie jedynie pukla włosów, gdzie znajduje się pakunek z pieniędzmi.

34 B. Méheust, A Historical Approach to Psychical Research. The Case of Alexis Didier (1826-1886), [online] http://bertrand.meheust.free.fr/documents/conf-esalem.pdf [dostęp: 3.09.2015].

35 Jenny Lind. An After-construction, [online] www.iconsofeurope.com [dostęp: 3.05.2015]. 
bardzo ogólnikowo, nie negując ani nie aprobując teorii szwedzkich badaczy. Warto przytoczyć tutaj wypowiedź Wróblewskiej-Straus z 13 października 2003 roku:

Teoria ta będzie służyć dobrze sprawie, jeżeli w przyszłości, być może najbliższej, uda się odszukać dokumenty, które na zawsze rozwiążą tę sporną kwestię. Nie wykluczam, że Jenny Lind zakochała się w Chopinie i miała plany matrymonialne w stosunku do niego ${ }^{36}$.

Na razie jednak takich dokumentów nie odnaleziono, pomimo tego, że od tej wypowiedzi minęło już ponad dziesięć lat. Jane Stirling jawi się wciąż jako najbardziej prawdopodobny darczyńca.

\section{Działalność Jane Stirling po śmierci kompozytora}

Po śmierci Fryderyka Chopina Jane Stirling zajęła się zorganizowaniem jego pogrzebu. Co prawda, nie potwierdzają tego żadne bezpośrednie źródła, jednak opinia badaczy jest jednoznaczna ${ }^{37}$ : to Jane zatroszczyła się - wspierając we wszystkim Ludwikę Jędrzejewicz - o przygotowanie tej uroczystości, poczynając od wybrania kościoła, przez ułożenie zaproszeń, aż po zwrócenie się do najlepszych śpiewaków w Paryżu, by wykonali Requiem Wolfganga Amadeusza Mozarta. Prawdopodobnie Jane opłaciła też wszystkie bieżące wydatki związane z pogrzebem, co Ludwika potraktowała jako pożyczkę, którą później sumiennie spłaciła. Świadczy o tym list Katherine Erskine do Ludwiki Jędrzejewicz, w którym siostra Jane Stirling dziękuje „[...] za nadesłanych 4529 franków i dodaje, że kwit wystawiony przez Panią Jędrzejewicz zniszczyła" ${ }^{38}$.

Kilka dni po pogrzebie kompozytora, w piątek 30 listopada 1849 roku, na ulicy Jeûneurs $42^{39}$ odbyła się wyprzedaż ruchomości po Chopinie, w której Jane uczestniczyła ${ }^{40}$. Nie wiemy, jaką część spadku po Fryderyku zlicytowała Stirling, można snuć tylko domysły. Édouard

36 Tamże.

37 Por. M. Steen, The Lives and Times of the Great Composers, Oxford 2004, s. 132.

38 M. Karłowicz, dz. cyt., s. 347.

39 Tamże, s. 252.

40 „Zdążyłam na czas aby sprzeciwić się rozdaniu bielizny. Nie mogłabym na to pozwolić, aby została rozdana temu i owemu”. List Jane Stirling do Ludwiki Jędrzejewicz, Paryż, 12 czerwca 1850, cyt. za: H. Wróblewska-Straus, Listy..., dz. cyt., s. 114. 
Ganche uważał, że „Stirling pierwsza kupiła wszystko, co znajdowało się w mieszkaniu [...] i połowę tego oddała Ludwice" ${ }^{41}$. Nazwisko Jane nie figuruje wprawdzie w akcie sprzedaży, ale wiele przedmiotów kupiono anonimowo. Wydaje się, że mogły one zostać nabyte właśnie przez Szkotkę, gdyż, jak sugeruje Delapierre, „znając jej takt i dyskrecję wolała zachować anonimowośćc" 42 . Potwierdza to korespondencja między Stirling a Ludwiką Jędrzejewicz. Dowiadujemy się z niej, że wiele przedmiotów należących do Fryderyka było w posiadaniu Jane, która sukcesywnie wysyłała je rodzinie kompozytora w Warszawie oraz jego znajomym. Oto przykładowe cytaty z listów Jane Stirling do Ludwiki:

W skrzyni na książki nie było dość miejsca na firanki. Włożyliśmy je do drugiej skrzyni przedzielonej na dwie części, w drugiej połowie umieściliśmy kwiaty. Przesadzi je Pani do doniczek z polską ziemią ${ }^{43}$.

Małe krzesełko jest wysłane razem z fortepianem. Ma już pani poduszkę z czerwonej skóry, którą on własnymi rękami tak często na nie kładł ${ }^{44}$.

Część pamiątek Stirling pozostawiła sobie i stworzyła z nich „muzeum chopinowskie” w Szkocji ${ }^{45}$. Niestety, wiemy o nim niewiele. Był to specjalny pokój w Calder House, „znajdował się tam fortepian Pleyela [...], przepysznie i kunsztownie inkrustowana szkatułka podarowana przez Rothschilda; zbiór wszystkich wycinków z gazet francuskich i angielskich [...], dalej nakrycia, dywany, fotele, poduszki [...] i rozmaite drobniejsze zbytku przedmioty" ${ }^{46}$. Zgodnie z jej ostatnią wolą, wszystkie przedmioty $\mathrm{z}$ "muzeum” zostały przekazane matce Chopina i wysłane do Warszawy. Większość z nich została zniszczona w 1861 roku, w czasie masakr dokonanych przez armię rosyjską w Warszawie ${ }^{47}$. Najwięcej pamiątek znajdowało się w mieszkaniu siostry kompozytora, Izabeli Barcińskiej, którego wyposażenie zostało spalone w odwecie za zamach na rosyjskiego generała Fiodora Berga.

41 É. Ganche, Dans le souvenir de Frédéric Chopin, Paris 1925, s. 103-149.

42 A. Delapierre, Spadek po Chopinie, „Rocznik Chopinowski” 22/23 (1996/1997), s. 244.

43 H. Wróblewska-Straus, Listy..., dz. cyt., s. 106.

44 Tamże, s. 113.

45 M. Karasowski, Fryderyk Chopin. Życie - listy - dzieła, t. 2, Warszawa 1882, s. 209.

46 Tamże, s. 210.

47 D.C.F. Wright, dz. cyt., s. 14. 
Jane uważała, że pamiątki powinny trafić do osób, które Chopin cenił. I tak, kiedy księżna Elżbieta Czernyszew chciała kupić od Stirling stoliczek należący do kompozytora, ta odpowiedziała, że przekazuje jej go za darmo w imieniu Ludwiki Jędrzejewicz, bo wie, iż księżna i jej córka uwielbiały Chopina ${ }^{48}$. Jane Stirling traktowała rzeczy należące do Chopina jak relikwie, nie uważając się jednak za ich właścicielkę (podobnie traktowała też pozostawione przez Chopina kompozycje, o czym świadczy następujący cytat: „Pokazałam mu dwojaka w d-moll. [...] Usilnie prosił mnie, żebym pozwoliłam mu skopiować go na poczekaniu. [...] Oświadczyłam mu, że nie mogę rozporządzać tym, co do mnie nie zależy"49).

Jane Stirling zakupiła także ostatni fortepian, na którym grał Fryderyk Chopin. Instrument ten stanowił kolejny prezent dla siostry kompozytora, Ludwiki Jędrzejewicz. Jane wykupiła go bezpośrednio od Camille’a Pleyela. Szkotka bardzo troszczyła się o to, by został on należycie zabezpieczony na czas przewozu do Polski, m.in. kupiła specjalną skrzynię z blachy cynkowanej, by ustrzec instrument przed wilgocią ${ }^{50}$. Na troskę Stirling wskazuje także następujący fragment: „Według informacji od Pani [Ludwiki Jędrzejewicz - przyp. P.P.] pochodzących podziela Pani pogląd, że fortepian winien być wysłany drogą morską [...] Pragnęłabym zabrać go ze sobą, aby zapewnić mu jak najlepszą opiekę" ${ }^{1}$.

Fortepian ten przez kilka pokoleń należał do rodziny Ludwiki. Jej wnuczka Maria Ciechomska sprzedała go 3 listopada 1924 roku Muzeum Narodowemu w Warszawie za 3108 złotych. W czasie II wojny światowej instrument został wywieziony do Pałacu Fishorn w Austrii. Po wojnie wrócił do Polski, a w 1968 roku Muzeum Narodowe podarowało go Towarzystwu im. Fryderyka Chopina. Obecnie fortepian znajduje się w zbiorach Narodowego Instytutu Fryderyka Chopina i prezentowany jest w Muzeum Fryderyka Chopina w Warszawie. Warto dodać, że identyfikacja fortepianu po wojnie była możliwa dzięki odręcznej dedykacji Jane Stirling na listwie zaczepowej w ogonie instrumentu: „pour Louise”. Po śmierci Fryderyka Chopina Jane Wilhelmina Stirling prowadziła także album, w którym zbierała wycinki z gazet dotyczące kompozytora. Wspomniany dziennik składa się ze

48 M. Karłowicz, dz. cyt., s. 333 .

49 List Jane Stirling do Ludwiki Jędrzejewicz, Paryż, 2-3 lipca 1852, cyt. za: H. Wróblewska-Straus, Listy..., dz. cyt., s. 156.

50 Tamże, s. 115.

51 Cyt. za: tamże, s. 113. 
103 stron oraz okładki. Pierwsza zamieszczona w nim wzmianka pochodzi z 19 października, a ostatnia z 4 grudnia 1849 roku, w sumie zawiera 24 wycinki $z$ gazet $^{52}$. W ten sposób w jednym miejscu zgromadzone zostały wszystkie informacje ukazujące się w gazetach bezpośrednio po śmierci kompozytora. W 1850 roku Stirling podarowała album malarzowi Teofilowi Kwiatkowskiemu. Dziś dokument ten znajduje się w zbiorach NIFC (sygnatura M/2948) i jest prezentowany w Muzeum Fryderyka Chopina w Warszawie.

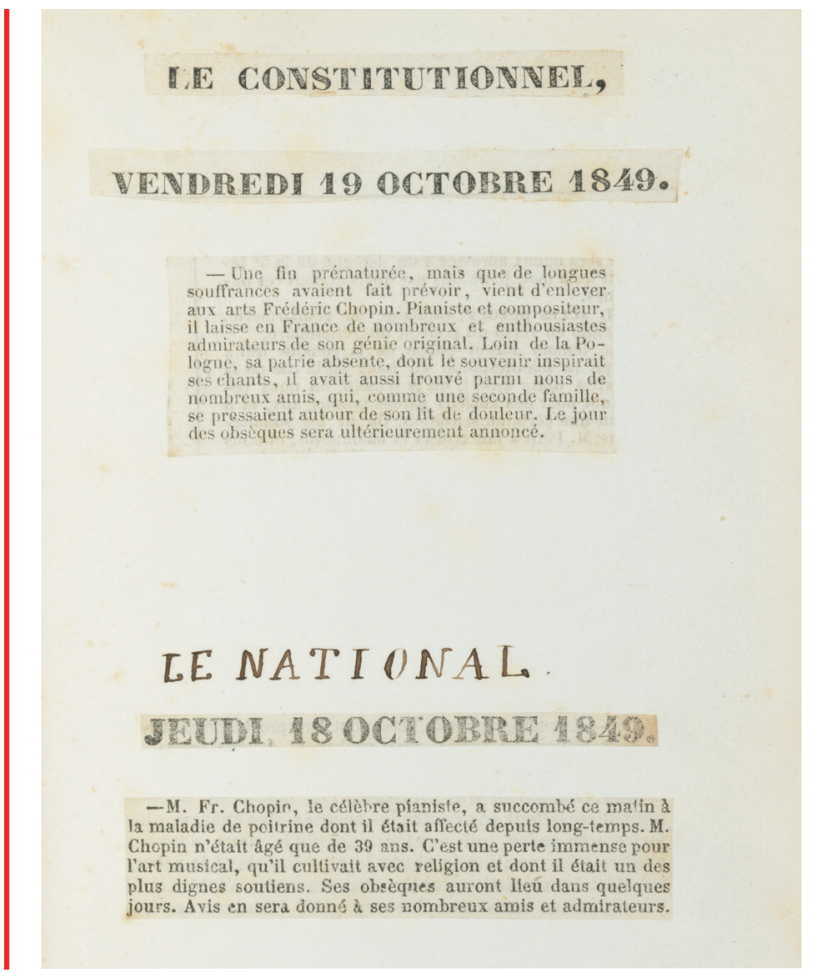

Ilustracja 1. Jedna ze stron Albumu Jane Stirling (M/2948).

52 Są to fragmenty następujących pism: „Le Journal des Débats” (4), „Le Constitutionel”, "Le Courrier Français”, „Le Credit”, „Le National”, „Le Messager des Théâtres et des Arts”, „L'Odre”, „L'Opinion Publique”, „Revue et Gazette des Théâtres”, „La Presse” (2), „Revue et Gazette Musicale de Paris”, „La Gazette de la France Musicale”, „L'Illustration. Journal Universel”, „La Tribune des Peuples”, „L'Artiste. Revue de Paris”, „The Daily News”, „John Bull”, „Le Pays” (2), „Le Siècle” (2), „L'Assamblée Nationale”, „Revue de la Quinzaine”, „La Réforme”, „Journal de Rouen”. 
Należy podkreślić, iż Stirling sporząazała album w czasie, kiedy nikt nie myślał, że gazety codzienne staną się obiektami zainteresowania naukowego, że będą pieczołowicie gromadzone, digitalizowane i udostępniane. Album stanowi bardzo ważne źródło informacji o kompozytorze. Odnajdujemy tu potwierdzenie faktów związanych ze śmiercią i pogrzebem Chopina (np. kto śpiewał podczas pogrzebu kompozytora i kiedy opinia publiczna dowiedziała się o jego śmierci). Znajdują się w nim przede wszystkim artykuły informacyjne: wiadomości o zgonie, dacie pogrzebu ${ }^{53}$ itp. Są też wśród nich wspomnienia ${ }^{54}$ i krótkie biografie kompozytora.

Kolejną rzeczą, którą Jane zajęła się bezpośrednio po śmierci Chopina, było zlecenie Auguste’owi Clésingerowi zdjęcia maski pośmiertnej kompozytora. Kilka godzin po śmierci Chopina Clésinger zdjął dwa negatywy maski, następnie wykonał według nich odlewy w gipsie. Dzięki Jane rodzina kompozytora otrzymała negatyw maski pośmiertnej (zawierał on dużą liczbę włosów kompozytora w masie gipsowej). Jane Stirling bardzo zależało na zdobyciu tego negatywu, choć nie wiadomo, jakimi pobudkami się kierowała. $Z$ samych listów wynika, że chodziło jej tylko o to, by ta bezcenna relikwia trafiła do rodziny kompozytora, gdyż to ona była jej „prawną właścicielką" ${ }^{55}$. Negatyw pozostawał w rękach krewnych kompozytora do roku 1922, kiedy to Maria Ciechomska przekazała go Muzeum Narodowemu w Warszawie. W czasie II wojny światowej został zniszczony. Zachował się jednak pozytyw, który obecnie znajduje się w zbiorach NIFC $(\mathrm{D} / 157)^{56}$. Prócz negatywu maski Stirling zamówiła dodatkowo u Clésingera „gipsową formę marmuru" ${ }^{57}$ - wyidealizowany obraz maski pośmiertnej

53 „Pan Fr. Chopin, sławny pianista, zmarł na chorobę piersiową, którą był dotknięty od dawna. [...] Jest to ogromna strata dla sztuki muzycznej. [...] Pogrzeb jego odbędzie się za kilka dni”. „Le National” 18.10.1849.

54 „Po długiej i straszliwej agonii Chopin umarł. [...] Jego osłabienie i cierpienia tak się wzmogły, że nie był już w stanie ani grać na fortepianie, ani komponować, najkrótsza nawet rozmowa męczyła go w sposób niepokojący. [...] Stąd to odosobnienie, $[\ldots]$ źle tłumaczone przez wielu, przypisywane przez jednych wzgardliwej dumie, przez innych czarnej melancholii, właściwościom w równym stopniu obcym charakterowi tego uroczego i znakomitego artysty”. „Le Journal des Débats" 27.10.1849.

55 Cyt. za: H. Wróblewska-Straus, Listy..., dz. cyt., s. 86.

56 H. Wróblewska-Straus, „Za miesiąc z Paryża więcej Wam napiszę”. Nowe pamiątki Chopinowskie w zbiorach TiFC, „Ruch Muzyczny” 1978, nr 25, s. 5.

57 Cyt. za: H. Wróblewska-Straus, Listy..., dz. cyt., s. 86. 
$\mathrm{w}$ formie marmurowej rzeźby (fotografia rzeźby znajduje się w zbiorach NIFC pod sygnaturą M/606).

Auguste Clésinger zajął się także zaprojektowaniem pomnika na grób kompozytora, a Jane od początku nadzorowała powstawanie monumentu (przy współpracy m.in. Eugène’a Delacroix, który przewodniczył komitetowi budowy pomnika ${ }^{58}$ ), dbała o najmniejsze detale i pozostawała w kontakcie z Ludwiką Jędrzejewicz, przekazując twórcom nagrobka sugestie rodziny, czego przykład znajdujemy w poniższym fragmencie listu do Ludwiki Jędrzejewicz z listopada 1850 roku: „Wspomniałam panom [twórcom nagrobka, komitetowi - przyp. P.P.], że w ogrodzeniu, zgodnie z życzeniem Pani Jędrzejewicz, powinny znajdować się drzwiczki, ażeby móc stawiać kwiaty" ${ }^{59}$. Stirling konsultowała też wszystkie pomysły z rodziną kompozytora. Kiedy pojawiała się jakakolwiek nowa inicjatywa, od razu pisała o tym Ludwice:

\section{[...] w liście 17-tym Panna Stirling donosi [Ludwice - przyp. P.P.], że powstał projekt dodania na pomniku słów następujących „né le 1-er mar $18 \ldots$ en Pologne, à Zelazowa-Wola, palatinat de Masovie, de Nicolas Chopin, et [...]"60. \\ Czy Pani Jędrzejewicz ma jakiś dzień pamiątkowy w czerwcu, który chciałaby przeznaczyć na odsłonięcie [pomnika - przyp. P.P.]? Czy rodzina życzy sobie, ażeby na grobowcu wyciąć jakąś cytatę biblijną?61}

Stirling zadecydowała także, że w bryle pomnika winno się zaprojektować specjalny otwór, do którego włożyć będzie można specjalnie wybrane rzeczy. Ona była również odpowiedzialna za wybór tychże przedmiotów. Znalazły się wśród nich dwa medaliony od Bovy’ego, skrzynka z rzeczami z Warszawy, papier z datą urodzenia i śmierci kompozytora, krzyżyk od Jane, medalion od Tellefsena oraz monety z roku urodzenia i śmierci Chopina ${ }^{62}$. Były to zatem przedmioty od najbliższej rodziny i od jednego $\mathrm{z}$ ulubionych uczniów kompozytora, z którymi Jane utrzymywała kontakty. To, że we wgłębieniu znalazł się

\footnotetext{
58 A. Chybiński, Fryderyk Chopin i Eugeniusz Delacroix, „Gazeta Lwowska. Przewodnik Naukowy i Literacki" 1907, nr 7, s. 600-601.

59 List Jane Stirling do Ludwiki Jędrzejewicz, Paryż, listopad 1850, cyt. za: M. Karłowicz, dz. cyt., s. 333 .

60 Tamże, s. 337.

61 Tamże, s. 335.

62 Tamże, s. 337.
} 
krzyżyk od Jane, jest niezwykle znamienne, świadczy - jak się wydaje - że uważała ona Chopina za najbliższą sobie osobę, której miejsce pochówku, zgodnie ze swą głęboko religijną postawą, wyposażyła w ten ważny symbol. Samo odsłonięcie pomnika było dla Stirling ważnym wydarzeniem - w jej pojęciu moment ten rozdzielał ją z kompozytorem na zawsze, był symbolem ostatecznej rozłąki. Dobitnie świadczy o tym korespondencja z Ludwiką Jędrzejewicz:

Będzie mi żal, gdy wszystko zostanie już urządzone z pedantyczną symetrią. Chętnie zachowałabym stan dotychczasowy ${ }^{63}$.

Będzie mi jakoś przykro, gdy wśród tego stanie marmur odgradzający nas od niego, gdy wszystko zostanie już urządzone i zakończone ${ }^{64}$.

Jane często odwiedzała grób kompozytora, czego liczne dowody znajdują się w wielokrotnie tu przywoływanych listach do Ludwiki. Dbała o to, by na grobie zawsze były świeże kwiaty. Wiedząc, jak bardzo Chopin kochał swoją ojczyznę, poprosiła Ludwikę o przesłanie słoika z polską ziemią, by mogła ją rozrzucić na grobie ${ }^{65}$. Zdarzało się też, że zostawiała kwiaty na grobie $\mathrm{w}$ imieniu rodziny kompozytora, co dowodzi jej wielkiego przywiązania i szacunku nie tylko do Chopina, ale i jego bliskich:

\section{Byłyśmy zaś 7-go. Złożyłam 12 wieńców wrzosowych od jego ukochanej Matki, Siostry i jej męża, od Pani i jej męża i Waszych dzieci, od Ciotki Zuzanny i od nas obu. Tam oto chodzimy z największą... przyjemnością, nie jest to właściwym słowem, lecz może tym, gdy brak już słów ${ }^{66}$.}

Oprócz opieki nad grobem oraz działań podejmowanych bezpośrednio po śmierci kompozytora Stirling starała się na różne sposoby chronić i zachować jego dorobek. Zajęła się m.in. ochroną autografów kompozytora. Jak wiemy, Chopin prosił, żeby wszystkie autografy kompozycji niewydanych za jego życia zostały spalone ${ }^{67}$, tak się jednak

63 H. Wróblewska-Straus, Listy..., dz. cyt., s. 122.

64 Tamże, s. 94.

65 Tamże, s. 114.

66 Tamże, s. 94.

67 „Reszta bez żadnego wyjątku ma być strawiona przez ogień, mam bowiem dla publiczności wielki szacunek i nie chcę, by na moją odpowiedzialność i pod 
nie stało. Jane Stirling bardzo zależało na ich wydaniu. Była w stałym kontakcie z Franchommem i Fontaną, a listy od nich dowodzą, że liczyli się oni z jej zdaniem:

\section{Przesyłam Pani [...] to, co Franchomme potrafił odczytać z ostatniego Mazurka [...]. Na początku przyniósł mi go na dwóch kartkach, gdyż nie ośmielił się połączyć obu części, ale dodał w basie jedną nutę (e) do (h) co stanowi całość 68 .}

W liście sporządzonym w dniach 2-3 lipca 1852 roku Jane Stirling zawarła listę pieśni - rodzaj rejestru autografów i dostępnych kopii. Lista ta jest bardzo ważnym dokumentem. Na tej właśnie podstawie Fontana wydał późniejszą publikację. Co więcej, oprócz znanych nam pieśni znalazły się na niej trzy jak dotąd zaginione: $O$, nie mów, System filozoficzny podstarościego oraz Że Bóg jest. Dowiadujemy się $\mathrm{z}$ niej również, ile autografów pieśni było w posiadaniu Stirling, jaką wagę do nich przywiązywała i jak dbała, by na nie należycie uważać69: „Powierzam cenne rękopisy Pani Veyret, która zapewni im specjalną opiekę i przechowa ten depozyt jak rzecz świętą"70.

Jane Stirling i w tym wypadku konsultowała wszystko z Ludwiką Jędrzejewicz, sama nie chciała podejmować ostatecznej decyzji w sprawie ewentualnego wydania. Uważała, że nie jest to rolą jej, lecz rodziny kompozytora, jednak pragnęła mieć wpływ na to, co zostanie wydane, jeżeli siostra kompozytora się na to zdecyduje. Podkreślała to bardzo dobitnie w swoich listach do Ludwiki: „Jeśli jest Pani zdecydowana na to, aby Melodie zostały wydane staraniem Fontany i Elsnera...”; „Jeśli wolno mi będzie udzielić Pani rady, sądzę, że byłoby dobrze aby Pani poleciła [...] wydać Fontanie..." ${ }^{71}$.

Stirling prosiła również Ludwikę o to, by sporządziła spis kompozycji Chopina wydanych i uzupełniła go o listę dzieł pozostających tylko w autografach. Dzięki temu spisowi następne pokolenia miały

moim nazwiskiem rozchodziły się utwory niegodne publiczności". List Wojciecha Grzymały do Augusta Léo, Paryż, koniec października 1849, cyt. za: B.E. Sydow, dz. cyt., s. 322.

68 List Jane Stirling do Ludwiki Jędrzejewicz, Paryż, 18 czerwca 1852, cyt. za: H. Wróblewska-Straus, Listy..., dz. cyt., s. 149.

69 Tamże, s. 157.

70 Tamże, s. 156.

71 Tamże. 
nie mieć problemów ze sprawdzeniem autentyczności dzieł Fryderyka Chopina. W ten sposób powstał rodzaj katalogu tematycznego zatytułowanego Kompozycje niewydane ${ }^{72}$. List, w którym Jane prosi o to Ludwikę, nie zachował się, widział go jednak Karłowicz i opisał w swej bezcennej publikacji ${ }^{73}$. Spis ten przechowywany jest dziś w zbiorach NIFC (sygnatura M/301). Znajduje się w nim aż 9 dzieł, których autografami obecnie nie dysponujemy. Gdyby więc nie skrupulatność Stirling, prawdopodobnie dziś nie wiedzielibyśmy nawet o ich istnieniu.

Oprócz nakłonienia Ludwiki do stworzenia listy kompozycji niewydanych, Jane Stirling w sposób systematyczny starała się przyczynić do zachowania spuścizny Chopinowskiej: tworzyła liczne spisy, listy, wykazy itd. Dziś nie jesteśmy nawet w stanie określić, ile ich powstało. W zbiorach NIFC znajdują się trzy takie wykazy: Spis dokumentów będących własnością Fryderyka Chopina (M/314), Wykaz uczennic i uczniów Fryderyka Chopina (M/459) oraz Wykaz nadawców listów do Fryderyka Chopina (M/460). Katalogi te nie zostały dotąd nigdzie należycie opisane. Spis dokumentów będących własnościa Fryderyka Chopina znajduje się na ekspozycji Muzeum Fryderyka Chopina w Warszawie, został jedynie wspomniany w Katalogu Zbiorów Muzeum TiFC z 1971 roku $^{74}$ oraz w dwóch artykułach: Hanny WróblewskiejStraus $^{75}$ oraz Jean-Jacques’a Eigeldingera ${ }^{76}$. Spis ten jest o tyle ważny, że dzięki zebranym przez Jane w jednym miejscu informacjom potrafimy odtworzyć program czy daty niektórych koncertów Chopina. Z kolei w Wykazie nadawców listów do Fryderyka Chopina Stirling wymienia listy m.in. od: księżnej de Sutherland, hrabiny Gainsborough, Księżnej Somerset, Panny Trottet ${ }^{77}$ oraz H.F. Broodwooda ${ }^{78}$. Jane wysłała tę listę wraz z wiadomością adresowaną do Ludwiki Jędrzejewicz, pisząc: „Sporządziłam listę tej korespondencji i zamieściłam ją wraz z listami”79.

72 Lista wszystkich zawartych tam utworów znajduje się m.in. w: M. Karłowicz, dz. cyt., s. $377-378$.

73 Tamże, s. 346.

74 Katalog zbiorów muzeum. Rękopisy, druki, grafika, fotografie, Warszawa 1971, s. 88.

75 H. Wróblewska-Straus, „Za miesiąc..., dz. cyt., s. 3-5.

76 J.-J. Eigeldinger, Koncerty Chopina $w$ Paryżu w latach 1832-1838, „Rocznik Chopinowski" 1987, $\mathrm{nr} 17$.

77 Zachowany w zbiorach NIFC, sygnatura M/445.

78 Zachowane w zbiorach NIFC, sygnatury M/434, M/436.

79 List Jane Stirling do Ludwiki Jędrzejewicz, Paryż, 12 czerwca 1850, cyt. za: H. Wróblewska-Straus, Listy..., dz. cyt., s. 115. 
Część z tych listów do dziś uznanych jest za zaginione, tak więc spis sporządzony przez Stirling stanowi jedyne świadectwo ich istnienia.

Powyższe dokumenty wskazują, jak ważne dla Stirling było zachowanie dla potomności każdej informacji o kompozytorze, nawet takiej, która - w chwili układania wykazów - na pozór miała niewielkie znaczenie. Ich powstanie wynikło na pewno z jej uwielbienia dla wszystkiego, co łączyło się z ukochanym mistrzem, a także z zamiłowania do porządku i skrupulatności, jakie cechowały wszelkie jej działania. Z uwagi na zawiłe i niekiedy tragiczne losy spuścizny po kompozytorze spisy te okazały się mieć wielką wartość dokumentalną.

Po Jane Stirling zachowało się także 7 tomów utworów Fryderyka Chopina, które stanowiły jej egzemplarze lekcyjne. Są one cennym źródłem uzupełniającym wiedzę o utworach, estetyce wykonawczej oraz metodach nauczania Chopina, gdyż zawierają własnoręczne adnotacje kompozytora oraz Jane Stirling, takie jak: palcowanie, dodatkowe wskazania tempa i charakteru, pedalizacji, dynamiki, frazowania, artykulacji czy agogiki, modyfikacje tekstu, sposoby wykonania ozdobników. Adnotacje tego typu znalazły się w sumie w 63 utworach. Egzemplarze lekcyjne Jane Stirling nie są oczywiście jedynym tego typu świadectwem pracy Chopina z uczniami - dysponujemy obecnie kilkoma podobnymi dokumentami, z których jako najważniejsze należy wymienić egzemplarze Ludwiki Jędrzejewicz, Camilli O’Meara-Dubois i Auguste’a Franchomme'a. Wiele adnotacji zapisanych przez kompozytora zawartych jest w materiałach lekcyjnych wszystkich wyżej wymienionych uczniów. Jednak przykładowo palcowanie w Mazurku f-moll op. 7 nr 3 czy Nokturnie Des-dur op. 27 nr 2 znalazło się tylko w zbiorze Stirling. Warto zaznaczyć także, iż Jane miała dostęp do egzemplarzy Ludwiki i wprowadziła do nich znaczną liczbę adnotacji. Z kolei część uwag, które odnajdujemy w egzemplarzach Stirling, została prawdopodobnie skopiowana przez nią z egzemplarzy Ludwiki ${ }^{80}$.

W owych siedmiu tomach zebrane zostały prawie wszystkie utwory Chopina ${ }^{81}$. Na końcu ostatniego tomu znajduje się stworzony przez Chopina swoisty spis treści z tabelą wszystkich incipitów muzycznych. Prawdopodobnie tabela ta, a także własnoręczny wpis kompozytora przy op. 47: „To ja poprawiałem wszystkie te nuty”, miały być rodzajem

80 J.-J. Eigeldinger, Chopin w oczach..., dz. cyt., s. 270.

81 Brakuje: Poloneza g-moll, Mazurków g-moll i B-dur, Grand Duo Concertant E-dur, Wariacji VI z Hexameronu, Mazurka wydanego w roku 1841. 
gwarancji dla potencjalnego wydawcy i poświadczać o autentyczności wszystkich utworów zebranych w tymże zbiorze ${ }^{82}$. Być może o tej właśnie tabeli Chopin pisał w liście do Wojciecha Grzymały z dnia 30 października 1848 roku ze Szkocji: „Napisałem rodzaj porządku z moimi gratami do zrobienia w przypadku, gdybym gdzieś zdechł"83. Prawdopodobne jest też, że Chopin sporządził ów spis za namową Jane Stirling. Po raz kolejny odnosząc się do jej skrupulatności, należy wspomnieć jeszcze o napisanym przez nią oświadczeniu dotyczącym tego, które $\mathrm{z}$ utworów zgromadzonych $\mathrm{w}$ tych siedmiu tomach grała na lekcjach u Chopina, jaka część palcowania została przez niego opracowana oraz kto sporządził spis treści ${ }^{84}$. W świetle tych wszystkich informacji nie dziwi osąd J.-J. Eigeldingera, że „wśród adnotowanych nut $[\ldots]$ należących do uczniów lub bliskich Chopina, egzemplarze Stirling stanowią źródło najważniejsze"85.

Wszystkie te tomy w roku 1927 weszły w posiadanie francuskiego chopinologa Édouarda Ganche’a, który otrzymał je od spadkobierczyni Jane Stirling, Anne Hunson. Wkrótce na ich podstawie wydano The Oxford Original Edition of Frédéric Chopin (Oxford University Press 1928-1932).

Po śmierci Chopina zastanawiano się, kto napisze jego pierwszą biografię. Wiadome było, że nastąpi to w niedługim czasie po pogrzebie. Prawdopodobnie najwcześniej chciał przystąpić do tej pracy Wojciech Grzymała ${ }^{86}$. Dzieło dotyczące życia i twórczości Chopina jako pierwszy skończył jednak Franciszek Liszt w roku 1852. Wiemy, że Stirling miała swój udział w powstaniu obu tych biografii. Grzymała konsultował swoją pracę bezpośrednio z Jane; uważała ona, że część tej pracy jest dobra, część jednak należałoby poprawićs ${ }^{87}$. Nieco inaczej miała się rzecz przy tworzeniu, bardzo przez Stirling skrytykowanej, biografii Liszta. Węgierski kompozytor wysłał do Ludwiki 14 listopada 1849 roku kwestionariusz dotyczący życia kompozytora, ona jednak na pytania zadane przez Liszta nie odpowiedziała. Zamiast niej informacji udzieliła Stirling, przy czym odpowiedzi przesłała do korekty Ludwice, co zdaje się wskazywać, że siostra kompozytora mogła po prostu poprosić ją o pomoc w tym względzie.

82 J.-J. Eigeldinger, Chopin w oczach..., dz. cyt., s. 248.

83 Cyt. za: B.E. Sydow, dz. cyt., s. 283.

84 J.-J. Eigeldinger, Chopin w oczach..., dz. cyt., s. 244.

85 Tamże, s. 250.

86 M. Karłowicz, dz. cyt., s. 338.

87 Tamże. 
O czym świadczą odpowiedzi udzielone przez Jane? Przede wszystkim o tym, że o życiu Chopina wiedziała naprawdę dużo (pojawiają się m.in. informacje o ojcu, Liceum Warszawskim i okolicznościach opuszczenia przez kompozytora Polski), a także o tym, że za wszelką cenę chciała ukazać kompozytora w jak najlepszym świetle: „Śmierć jego była zgonem duszy czystej, pełnej rezygnacji i wiary. Ani nawet najlżejsza obawa życia pozagrobowego nie pojawiała się i nie zamroczyła ostatnich chwil jego" 88 . W swoich odpowiedziach starała się nawet skłonić Liszta, by nie pisał wiele o relacji Chopina i George Sand. Na pytanie: „Jakie cechy przybrał pod koniec stosunek jego z Panią Sand?”, odpowiedziała następująco: „Życie domowe Chopina było dla niego świątynią, do której nie dawał przystępu; był zbyt skąpy w szczegółach, aby się miano niemi zajmować w jego życiorysach" ${ }^{89}$. W odpowiedzi na kolejne pytanie dodała: „Nie mówił o niej [George - przyp. P.P.] w ostatnich chwilach życia" ${ }^{90}$. Trudno dziś powiedzieć, na ile te wypowiedzi odpowiadają prawdzie, a na ile wynikają z oczywistej ze strony Jane niechęci do długoletniej towarzyszki życia kompozytora.

Biografia pióra Franciszka Liszta do dziś stanowi obiekt kontrowersji w środowisku muzycznym - jak twierdzi Mieczysław Tomaszewski, „jest [ona] przedziwną mieszaniną faktów i zmyśleń"91. Chopin nie został w niej przedstawiony jako postać doskonała, a więc i opinia Stirling o tej książce nie mogła być pozytywna, czemu dała wyraz w listach do Ludwiki:

Osoba ze wszech miar kompetentna dała mu ocenę powołując się na obiegowe porzekadło: On napluł na talerz, aby obrzydzić jadło innym" - on napisał po to, aby nikt inny nie chciał napisać. Zaproponowałam Przyjacielowi ze wsi wspólne odczytanie listów dla wynotowania fałszów, na które należy zwrócić uwagę ${ }^{92}$.

88 Prawdopodobnie odpowiedź Jane Wilhelminy Stirling na list Franciszka Liszta, po 14 listopada 1849 , cyt. za: tamże, s. 364 .

89 Tamże, s. 361.

90 Tamże, s. 364.

91 M. Tomaszewski, Liszta fantazja, parafraza i wariacja, rozm. przepr. M. Nadzieja, [online] http://www.dwutygodnik.com/artykul/2979-liszta-fantazja-parafraza-i-wariacja.html [dostęp: 20.05.2016].

92 List Jane Stirling do Ludwiki Jędrzejewicz, Paryż, 5 marca 1852, cyt. za: H. Wróblewska-Straus, Listy..., dz. cyt., s. 140. 
Wydaje się, że Stirling miała żal do Liszta, że ten źle wykorzystał odpowiedzi, których mu udzieliła. Świadczy o tym cytat $\mathrm{z}$ listu do Ludwiki z 2-3 lipca 1852 roku. Jane pisze w nim do siostry Chopina, by ta nie robiła sobie wyrzutów z powodu tego, że to nie ona udzieliła na nie odpowiedzi: „On by ich użył na chybił-trafil, a potem odpowiedzialność za to spadłaby na Panią"93.

\section{Podsumowanie}

Jane Wilhelmina Stirling zawsze pozostawała w cieniu Fryderyka Chopina. Postać Chopina, jego osobowość, zasługi jako kompozytora i wielkiego Polaka są tak ogromne, że i podczas pisania tej pracy często duch genialnego twórcy dominował nad skromną postacią „nudnej Szkotki"94. Jej rola w życiu Chopina, a także w kultywowaniu pamięci o nim jest jednak nieoceniona. Zasługuje ona zatem na przyznanie jej honorowego miejsca w panteonie osób zasłużonych dla Fryderyka Chopina oraz dla polskiej kultury. Żywię nadzieję, że niniejszy artykuł przyczyni się do tego, że zaczniemy patrzeć na postać Jane Stirling nie jako na śmiertelnie zakochaną w kompozytorze uczennicę, ale przede wszystkim jako na osobę, która walnie przyczyniła się do zachowania jego spuścizny.

Jakże prorocze i wciąż aktualne są jej własne słowa $z$ listu do Ludwiki Jędrzejewiczowej: „zawsze pozostanie jeszcze coś do zrobienia dla niego [Fryderyka Chopina - przyp. P.P.]"95. Nie powinniśmy zapominać o tych słowach, ale nie powinniśmy również zapominać o ich autorce. Parafrazując jej myśl: zawsze pozostanie jeszcze coś do odkrycia o Jane Stirling.

\section{Bibliografia}

Dokumenty i pamiątki96

Album Jane Stirling (M/2948).

Kompozycje niewydane (M/301).

93 Tamże, s. 155.

94 B.E. Sydow, dz. cyt., s. 289.

95 H. Wróblewska-Straus, Listy..., dz. cyt., 149.

96 Oznaczenia w nawiasach odnoszą się do sygnatur Narodowego Instytutu Fryderyka Chopina. 
Spis dokumentów będących własnościa Fryderyka Chopina (M/314).

Wykaz nadawców listów do Fryderyka Chopina (M/460).

Wykaz uczennic i uczniów Fryderyka Chopina (M/459).

\section{Literatura przedmiotu}

The Biographical Dictionary of Scottish Women. From the Earliest Times to 2004, red. E. Ewan, S. Innes, S. Reynolds, Edinburgh 2006.

Bone A.E., Jane Wilhelmina Stirling, 1804-1859. The First Study of the Life of Chopin's Pupil and Friend, Chipstead 1960.

Delapierre A., Spadek po Chopinie, „Rocznik Chopinowski” 1996/1997, nr 22-23.

Eigeldinger J.-J., Chopin w oczach swoich uczniów, tłum. Z. Skowron, Kraków 2010.

Eigeldinger J.-J., Koncerty Chopina w Paryżu w latach 1832-1838, „Rocznik Chopinowski” 1987, nr 17.

Ganche É., Dans le souvenir de Frédéric Chopin, Paris 1925.

Jorgensen C. i J., Chopin and the Swedish Nightingale, Brussels 2003.

Karasowski M., Fryderyk Chopin. Życie - listy - dzieła, Warszawa 1882.

Karłowicz M., Niewydane dotąd pamiatki po Chopinie, Warszawa 1904. Katalog zbiorów muzeum. Rękopisy, druki, grafika, fotografie, Warszawa 1971.

Kobylańska K., ,Spowiedź” Ludwiki, „Ruch Muzyczny” 1968, nr 20-21. Méheust B., A Historical Approach to Psychical Research. The Case of Alexis Didier (1826-1886), [online] http://bertrand.meheust.free.fr /documents/conf-esalem.pdf [dostęp: 3.09.2015].

Memoir of Madame Jenny Lind-Goldschmidt, t. 1, red. H.S. Holland, W.S. Rockstro, London 2001.

Musielak H, Dokumenty dotyczace spadku po Chopinie, „Ruch Muzyczny" 1978, nr 14-16.

Niecks F., Fryderyk Chopin jako człowiek i muzyk, tłum. A. Buchner, Warszawa 2011.

Steen M., The Lives and Times of the Great Composers, Oxford 2004. Sydow B.E., Korespondencja Fryderyka Chopina, t. 1-2, Warszawa 1955. Szulc T., Chopin in Paris. The Life and Times of the Romantic Composer, New York 1998.

Tomaszewski M., Liszta fantazja, parafraza $i$ wariacja, rozm. przepr. M. Nadzieja, [online] http://www.dwutygodnik.com 
/artykul/2979-liszta-fantazja-parafraza-i-wariacja.html [dostęp: 20.05.2016].

Weber B., Chopin, Wrocław 2000.

Wierzyński K., Życie Chopina, Białystok 1990.

Willis P., Chopin in Britain. Chopin's Visits to England and Scotland in 1837 and 1848. People, Places and Activities, Durham 2009.

Wright D.C.F., Frederick Chopin, [online] http://www.wrightmusic.net /pdfs/frederick-chopin.pdf [dostęp: 3.09.2016].

Wróblewska-Straus H., Listy Jane Wilhelminy Stirling do Ludwiki Jędrzejowiczowej, „Rocznik Chopinowski” 1980, nr 12.

Wróblewska-Straus H, „Za miesiąc z Paryża więcej Wam napiszę”. Nowe pamiątki chopinowskie w zbiorach TiFC, „Ruch Muzyczny” 1978, nr 25.

\section{Abstract}

\section{The role of Jane Wilhelmina Stirling in Fryderyk Chopin's life and in preserving memory and legacy of the composer}

The role of Jane Wilhelmina Stirling in Fryderyk Chopin's life as well as in preserving his legacy is nowadays underestimated. Jane Stirling was not only Chopin's pupil, but also his patron. She organized a concert tour to England and Scotland for him and tried to support the composer financially. Moreover, she defrayed the costs of the composer's funeral and erecting his gravestone. After his death, she focused on what Chopin had left passing away. It is thought that she purchased most of the items from his last apartment; she acquired also the last piano the composer had played. She tried to protect the autograph manuscripts he had left, and attempted to arrange the publication of compositions that had been retained only in a sketch form.

\section{Keywords}

Jane Wilhelmina Stirling, Fryderyk Chopin, Romantic music, Chopin’s legacy 